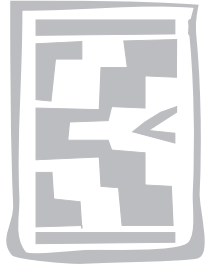

\title{
A serological survey for antibodies to foot-and-mouth disease virus in indigenous Tswana goats and sheep in Kasane, Maun and Shakawe districts in northwestern Botswana
}

\author{
J.M.K. HYERA ${ }^{1}$, M. LETSHWENYO², K.B. MONYAME¹, G. THOBOKWE', A.R. PILANE², \\ N. MAPITSE ${ }^{2}$ and E.K. BAIPOLEDI ${ }^{1}$
}

\begin{abstract}
HYERA, J.M.K., LETSHWENYO, M., MONYAME, K.B., THOBOKWE, G., PILANE, A.R., MAPITSE, N. \& BAIPOLEDI, E.K. 2006. A serological survey for antibodies to foot-and-mouth disease virus in indigenous Tswana goats and sheep in Kasane, Maun and Shakawe districts in northwestern Botswana. Onderstepoort Journal of Veterinary Research, 73:143-147

A serological survey was conducted in apparently healthy, unvaccinated indigenous Tswana goats and sheep in Kasane, Maun and Shakawe districts in northwestern Botswana in order to determine in these animals, the levels of exposure to the South African Territories (SAT) serotypes: SAT 1, SAT 2 and SAT 3 of foot-and-mouth disease virus (FMDV). A total of 250, 142 and 134 goat sera originating respectively from Kasane, Maun and Shakawe districts were tested for FMDV antibodies against the three SAT serotypes by the liquid phase blocking enzyme-linked immunosorbent assay and 26 of 250 $(10.4 \%), 5$ of $142(3.5 \%)$ and 18 of $134(13.4 \%)$ were positive either to SAT 1 or SAT 3, or to both serotypes.None of the goats' sera was positive to SAT 2 serotype.All sheep sera $(n=9)$ tested negative against all three serotypes of the virus. The findings are discussed in relation to results of other serological surveys carried out elsewhere.
\end{abstract}

Keywords: Botswana, FMD antibodies, FMD virus, indigenous goats, indigenous sheep

\section{INTRODUCTION}

Several free-living game animal species, particularly the African buffalo, Syncerus caffer, are important reservoirs of foot-and-mouth disease virus (FMDV) for livestock in southern Africa (Bengis, Thomson, Hedger, De Vos \& Pini 1986). Some of these species occur in large numbers in Botswana, especially along the Chobe River, the Okavango Delta and, as such, the two areas are recognized as the main foot-andmouth disease high-risk zones in the country.

Goats and sheep can be infected experimentally with FMDV (Dellers \& Hyde 1964; Geering 1967; Burrows

1 Botswana National Veterinary Laboratory, Private Bag 0035, Gaborone

2 Department of Animal Health and Production, Private Bag 0032, Gaborone, Botswana

Accepted for publication 16 March 2006-Editor
1968; McVicar \& Sutmoller 1968; Anderson, Doughty \& Anderson 1976) and natural infection with FMDV has been reported both in sheep (Zaikin 1959; Littlejohn 1970; Hedjazi, Ansari \& Nadalian 1972) and in goats (Hedjazi et al. 1972). Carrier states have been demonstrated both in sheep (Burrows 1968; McVicar \& Sutmoller 1968, 1972) and in goats (McVicar \& Sutmoller 1968, 1972; Anderson et al. 1976).

It is estimated that there are about 2.2 million goats and 0.4 million sheep in Botswana (Anon. 1996). The role of goats and sheep in the epidemiology of FMD in Botswana is not known. The study reported here was carried out in order to determine the level of exposure of Tswana goats and sheep to the South African Territories (SAT) serotypes of FMDV in northwestern Botswana with the ultimate goal of highlighting the epidemiological roles that these animals might play in the transmission of the disease to cattle. 


\section{MATERIALS AND METHODS}

\section{Serum samples}

Individual healthy, unvaccinated Tswana goats and sheep were bled aseptically from the jugular vein using plain vacutainer tubes. The blood samples were held on ice in a box to prevent haemolysis and after the blood had coagulated serum was harvested into sterile tubes which, after identification, were properly packed in a cool box and thereafter transported to the National Veterinary Laboratory (NVL) in Gaborone by the quickest available means.
A total of 526 goat sera (250 from Kasane, 142 from Maun and 134 from Shakawe) and nine sheep sera (from Kasane) were submitted to the NVL where they were stored at $-20^{\circ} \mathrm{C}$ until used. The age of the animals from which blood samples were taken was also recorded.

\section{Serum antibody assay}

Sera were tested for FMD antibodies against SAT 1, SAT 2 and SAT 3 serotypes of FMDV in microtitre enzyme-linked immunosorbent assay (ELISA) plates

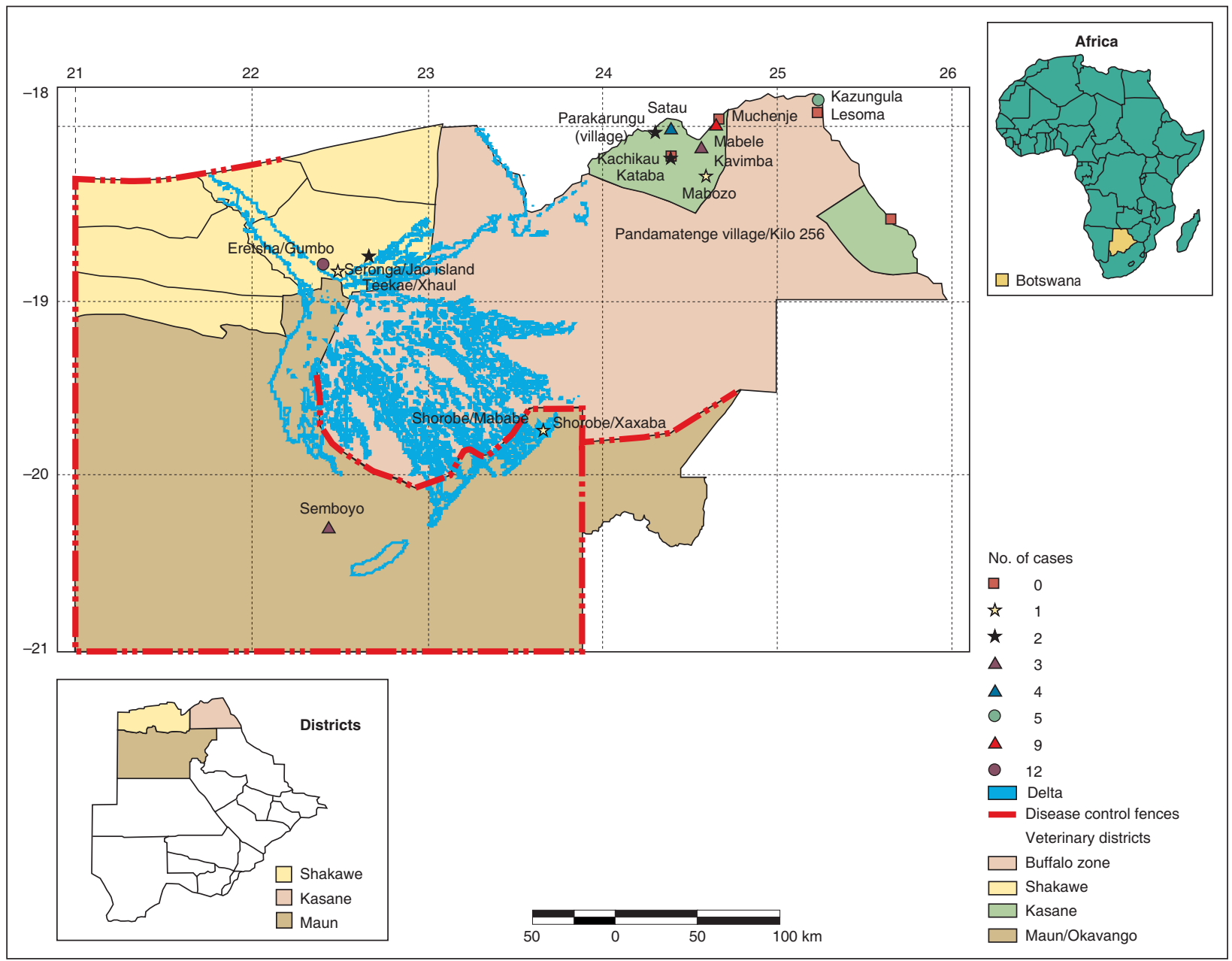

FIG. 1 Map of northwestern Botswana illustrating the geographical distribution of seropositive goats

TABLE 1 Prevalence of FMD antibodies in indigenous goats in northwestern Botswana

\begin{tabular}{|l|c|c|c|}
\hline District & Number of sera tested & Number of sera positive & Prevalence $(\%) \pm$ SE $^{1}$ \\
\hline Kasane & 250 & 26 & $10.40 \pm 3.78$ \\
Maun & 142 & 5 & $3.52 \pm 3.03$ \\
Shakawe & 134 & 18 & $13.43 \pm 5.77$ \\
\hline
\end{tabular}

\footnotetext{
1 Standard error at $95 \%$ confidence
} 
(Nunc immunoplates, Maxisorp surface) by the liquid phase blocking ELISA (LPBE) using methods described elsewhere (Hamblin, Barnett \& Hedger 1986; Hamblin, Barnett \& Crowther 1986; Hamblin; Kitching, Donaldson \& Crowther 1987). The sera were tested in duplicate wells; firstly, the tests were performed on a screening basis at the fixed dilution of 1/16 (1/32 after antigen addition) and thereafter all positive and doubtful sera were semi-titrated from dilutions of 1/32-1/256 (after addition of antigen). Antigen and known positive and negative sera were included in each ELISA plate as controls.

Optical density (OD) values were determined at a wavelength of $492 \mathrm{~nm}$ using a microplate ELISA reader (Titer-tek Multiskan; Labsystems) linked to a compatible computer using ELISA data interchange (EDI) version 2.16 software (Genesi; Windows for microplate based assays). The antibody titres were calculated by the method of Kaerber (1931) and were expressed in logarithms to base $10\left(\log _{10}\right)$.

\section{Statistical analysis}

Prevalences or seropositivity rates were determined by dividing the total number of positive serum samples by the total number of samples tested (Thrusfield 1995) and were expressed as a percentage. Relative frequency was also calculated according to Thrusfield (1995) and was expressed as a percentage.The standard error (SE) of percentages at $95 \%$ confidences was calculated according to the method described by Swisnscow (1980). The statistical table of
Armitage (1971) was used to assess the statistical significance between prevalence rates. Probability $(P)$ values of $<0.05,<0.01$ and $<0.001$ were considered respectively, as significant, very significant and highly significant.

\section{RESULTS}

A total of 49 of the $526(9.30 \pm 2.50 \%)$ goat sera were seropositive to FMDV. Table 1 shows the prevalence of antibodies to FMDV in northwestern Botswana by district. The FMD antibody prevalences in Kasane and Shakawe were similar $(\Delta \%=3.03$, $\mathrm{SE}=3.52 ; P>0.05)$ but differed very significantly both between Kasane and Maun $(\Delta \%=6.08$, SE $=$ 2.47; $P<0.01)$ and between Maun and Shakawe $(\Delta \%=9.90, \mathrm{SE}=3.33 ; P<0.01)$. Table 2 presents the prevalences within various locations of the three districts; the highest prevalence was recorded in Kazungula, Kasane district followed by Jao Island in Shakawe district. The geographical distribution of the seropositive goats is illustrated in Fig. 1.

Table 3 presents the distribution of positive goat sera by age group.The frequency of positive test results was comparatively higher in the adult than in the young goats $(\Delta \%=42.8$, SE $=9.13 ; P<0.001)$.

Serotype-wise 45 of $526(8.50 \pm 2.38 \%), 0$ of 526 $(0 \%)$ and 9 of $526(1.70 \pm 0.62 \%)$ goat sera exhibited antibodies to SAT 1, SAT 2 and SAT 3, respectively. The seropositivity rate to SAT 1 was higher than that to SAT 3 and the difference between the

TABLE 2 Prevalence of FMD antibodies in indigenous goats within several locations of three districts in northwestern Botswana

\begin{tabular}{|l|l|c|r|}
\hline District & Location & $\begin{array}{l}\text { Number of positive sera } \\
\text { total sera tested }\end{array}$ & Prevalence (\%) \\
\hline Kasane & Kazungula & $5 / 12$ & 41.67 \\
& Kachikau & 0.23 & 0.00 \\
& Lesoma & $0 / 11$ & 0.00 \\
& Kilo 256 & $0 / 12$ & 16.98 \\
& Mabele & $9 / 53$ & 0.00 \\
& Muchenje & $0 / 12$ & 16.67 \\
& Mabozo & $1 / 16$ & 10.26 \\
& Satau & $4 / 39$ & 5.66 \\
& Kavimba & $3 / 53$ & 9.52 \\
\hline Maun & Parakurungu & $2 / 21$ & 25.00 \\
& Kataba & $2 / 8$ & 2.97 \\
& Senkoyo & $3 / 101$ & 3.33 \\
& Mababe & $1 / 30$ & 9.09 \\
\hline \multirow{2}{*}{ Shakawe } & Xaxaba & $1 / 11$ & 7.50 \\
& Xhau 1 & $3 / 40$ & 2.08 \\
& Xhau 2 & $1 / 48$ & 25.00 \\
& Gumbo & $2 / 8$ & 31.58 \\
\hline
\end{tabular}


Foot-and-mouth disease virus in indigenous Tswana goats and sheep in Botswana

TABLE 3 Distribution of positive goat sera by age group

\begin{tabular}{|l|c|c|}
\hline Age group & Number of positive sera & Relative frequency (\%) \\
\hline Adult ${ }^{1}$ & 35 & 71.40 \\
\hline Young $^{2}$ & 14 & 28.60 \\
\hline Total & 49 & 100.00 \\
\hline
\end{tabular}

1 More than one year

2 Less than one year

TABLE 4 Distribution of FMD antibody titres by SAT serotypes of FMD virus in indigenous Tswana goats in northwestern Botswana

\begin{tabular}{|l|r|r|r|}
\hline \multirow{2}{*}{ Titre $^{1}$} & \multicolumn{2}{|l|}{ Number of sera per SAT serotype } & SAT 3 \\
\cline { 2 - 4 } & SAT 1 & SAT 2 & 517 \\
\hline$<1.60$ & 481 & 526 & 9 \\
$\geq 1.60,<2.00$ & 36 & 0 & 0 \\
$>2.00$ & 9 & 0 & 0 \\
\hline
\end{tabular}

1 Expressed in $\log 10$

two rates is highly significant $(\Delta \%=6.80, \mathrm{SE}=1.34$; $P<0.001$ ). Table 4 shows the distribution of antibody titres against the three SAT serotypes in goats. None of the goats examined had positive test results to SAT 2 and none of the nine sheep sera tested had antibodies to all three SAT serotypes.

\section{DISCUSSION}

The occurrence of buffaloes in the northwestern districts of Botswana poses a constant threat of infection with FMDV to cattle, goats and sheep. Consequently, cattle in Kasane and Shakawe districts are vaccinated annually against the three SAT serotypes of the virus using inactivated trivalent (SAT 1, SAT 2 and SAT 3) vaccine. Goats and sheep on the other hand are not vaccinated against any of the FMDV serotypes, although during FMD outbreaks all three livestock species (cattle, goats and sheep) are subject to the same quarantine procedures normally put in place. Therefore demonstration of FMD antibodies either in goats or in sheep would indicate exposure to FMD field virus. The significantly high frequency of FMD antibodies occurring in adult goats is probably a reflection of this type of exposure, the African buffalo possibly being the primary source of virus. The FMD antibodies demonstrated in the small number of young goats are, perhaps, residues of declining maternally-derived antibodies.

A similar serosurvey in a FMD enzootic area in Kenya showed that both goats and sheep were frequently exposed to infection with FMDV as evidenced by a high proportion of seropositive animals (Anderson et al. 1976). No seropositive sheep was found in the present study. However, the number of sheep samples tested in this study is too small to justify making meaningful conclusions.

Natural infection of sheep with FMDV has been reported by Zaikin (1959), Littlejohn (1970) and, more recently, by Knowles, Samuel, Davies, Kitching \& Donaldson (2001). The disease in sheep and goats has been reported as occurring frequently in certain provinces of Iran (Hedjazi et al. 1972) and the frequency of occurrence was associated with the emergence of exotic strains of the virus particularly those strains belonging to SAT 1 such as $\mathrm{A}_{22}$ (Hedjazi et al. 1972). In the serosurvey reported here, the prevalence of FMD antibodies against SAT 1 in goats was significantly higher than that against the other SAT serotypes; this observation concurs with the findings of Hedjazi et al. (1972).

It is on record that goats and sheep become carriers after exposure to FMD virus (Burrows 1968; McVicar \& Sutmoller 1968, 1972). When investigating the occurrence of carrier state in indigenous goats and sheep in Kenya, Anderson et al. (1976) found a very low incidence of FMD carriers in goats but none in sheep. No records are available on the occurrence of FMDV carrier states in goats and sheep in Botswana. There are also no reports on the occurrence of clinical FMD in these animals in the country. More studies are therefore needed to determine the exact role, if any, of Tswana goats and sheep in the epidemiology of FMD in Botswana. 


\section{ACKNOWLEDGEMENTS}

This work was funded by the Government of Botswana. We thank the veterinary staff from the three districts and those at the NVL for their cooperation and technical assistance. We are grateful to $\mathrm{Dr}$ J.F.C. Nyange (NVL, Pathology Section) for critically reading the manuscript. The figure was made by $\mathrm{Mr}$ Calistus Bodilenyane and Mr Anthony Dingalo of the Veterinary Epidemiology and Economics Section of the Department of Animal Health and Production. This paper is published with permission of the Director of Animal Health and Production, Ministry of Agriculture, Republic of Botswana.

\section{REFERENCES}

ANDERSON, E.C., DOUGHTY, W.J. \& ANDERSON, J. 1976. The role of goats in the epizootiology of foot-and-mouth disease in Kenya. Journal of Hygiene, 76:395-402.

ANON. 1996. Agricultural Statistics. Ministry of Agriculture, Botswana, Gaborone.

ARMITAGE, P. 1971. Statistical methods in medical research, Oxford: Blackwell Scientific Publication.

BENGIS, R.G., THOMSON, G.R., HEDGER, R.S., DE VOS, V \& PINI, A. 1986. Foot-and-mouth disease and the African buffalo (Syncerus caffer). Carriers as a source of infection to cattle. Onderstepoort Journal of Veterinary Research, 53:6973.

BURROWS, R. 1968. The persistence of foot-and-mouth disease virus in sheep. Journal of Hygiene, 66:631-640.

DELLERS, R.W. \& HYDE, J.L. 1964.Response of sheep to experimental infection with foot-and-mouth disease virus. American Journal of Veterinary Research, 25:469-489.

GEERING, W.A. 1967. Foot-and-mouth disease in sheep.Australian Veterinary Journal, 43:485-489.
HAMBLIN, C., BARNETT, I.T.R. \& HEDGER R.S. 1986. A new enzyme-linked immunosorbent assay (ELISA) for the detection of antibodies against foot-and-mouth disease virus. Development and method of ELISA. Journal of Immunological Methods, 93:115-121.

HAMBLIN, C., BARNETT, I.T.R. \& CROWTHER, J.R. 1986. A new enzyme-linked immunosorbent assay (ELISA) for the detection of foot-and-mouth disease virus. Application. Journal of Immunological Methods, 93:123-129.

HAMBLIN, C., KITCHING, R.P., DONALDSON, A.I. \& CROWTHER, J.R. 1987. Enzyme-linked immunosorbent assay (ELISA) for the detection of antibodies against foot-andmouth disease virus. Evaluation of antibodies after infection and vaccination. Epidemiology and Infection, 99:733-744.

HEDJAZI, M., ANSARI, H. \& NADALIAN, M.G.H. 1972. Clinical study of foot-and-mouth disease outbreaks in unweaned lambs and kids in Iran. Revue de Médecine Vétérinaire, 123: 1085-1088.

KAERBER, G. 1931. Beitrag zur kollektiven Behandlung pharmakologischer Reihenversuche. Archives of Experimental Pathology and Pharmacology, 162:480-483.

KNOWLES, N.J., SAMUEL, A.R., DAVIES, P.R., KITCHING, R. P. \& DONALDSON, A.I. 2001. Outbreak of foot-and-mouth disease virus serotype $O$ in the UK by a pandemic strain. The Veterinary Record, 148:258-259.

LITTLEJOHN, A.I. 1970. Foot-and-mouth disease in sheep.State Veterinary Journal, 25:85-96.

McVICAR, J.W. \& SUTMOLLER, P. 1968. Sheep and goats as foot-and-mouth disease carriers. US Livestock Sanitary Association Proceedings, 72:400-406.

McVICAR, J.W. \& SUTMOLLER, P. 1972. Experimental footand-mouth disease in sheep and goats: an epizootiological model. Archiv für die Gesamte Virusforschung, 38:85-96.

SWINSCOW, T.D.V. 1980. Statistics at square one. London: British Medical Association.

THRUSFIELD, M. 1995. Veterinary epidemiology, $2^{\text {nd }}$ ed., London: Blackwell Scientific Publication.

ZAIKIN, D.G. 1959. Clinical picture of foot-and-mouth disease in sheep under pasture maintenance conditions. Veterinariya, 36:32-34. 